\title{
Formation of meat productivity, nutritional value and suitability of beef for baby food
}

\author{
Nikolay Zabashta ${ }^{1,}{ }^{*}$, Elena Golovko ${ }^{1}$, Irina Sinelshchikova ${ }^{1}$, and Anastasia Androsova \\ ${ }^{1}$ Department of Toxicology and Feed Quality, Federal State Budgetary Scientific Institution \\ Krasnodar Research Centre for Animal Husbandry and Veterinary Medicine, 4, Pervomayskaya \\ Street, 350055, Krasnodar, Russian Federation
}

\begin{abstract}
The research was carried out on the farms of the raw material zone of the Branch "Tikhoretsky Canned Meat Plant" of DANON RUSSIA JSC in two districts of the Krasnodar Territory. Experimental data on the productivity of bull-calves of dairy-meat black-and-white breed and its cross-breed with bulls of Kalmyk beef breed. In the "Rubin" farm of the Goryacheklyuchevsky district, the productivity of beef cattle of the Charolais breed was studied. In the study of raw meat for baby food, a comparative assessment of the quality and food safety of beef from blackand-white bulls; cross between black-and-white and Kalmyk breeds; Charolais breed was carried out. In terms of protein quality indicator (6.5), beef from Charolais bulls exceeded the rest (6.16 and 5.8). The Charolais breed has the best protein composition $(19.8 \mathrm{~g} / \mathrm{kg}$ of lysine, the limiting amino acid for the child's body). In terms of safety indicators, taking into account the maximum permissible levels of residual amounts of pesticides, toxic elements, antibiotics, meat raw materials from black-and-white bulls and a cross with the Kalmyk breed met the requirements of the interstate standard for raw materials for baby food.
\end{abstract}

\section{Introduction}

Beef remains the basis for the production of baby food. The number of beef cattle in Russia is insignificant. Beef production in our country is carried out through the breeding of dairy animals and combined production type. The share of beef from beef calves is about $2 \%$ of its total production [1].

The reserves for increasing the production of high-quality beef are an increase in the number of herds of beef cattle and industrial crossing of dairy and meat-and-dairy production breeds with beef bulls.

The level of meat productivity of cattle for the production of baby food, the quality and nutritional value of beef depend on the genetic potential (breed), the level and type of feeding and the conditions of keeping. Each of these factors has a certain effect on the morphological composition of the carcass, physicochemical and organoleptic indicators of the quality of raw meat, which can be characterized in different ways [2].

\footnotetext{
* Corresponding author: n.zabashta@bk.ru
} 
Crossbreeds surpass their maternal peers in terms of Pre-slaughter live weight, slaughter yield, feed conversion rate and quality of beef [3].

Due to the shortage of beef cattle, the production of beef suitable for baby and functional nutrition is possible, first of all, due to environmentally friendly technologies of growing and fattening bulls sold for meat [4].

Some researchers attach particular importance to consumer sensory perception of the value of beef of similar tenderness, but distinguished by high quality and marbling level [5, 6]. Other researchers believe that to assess the quality, physical and chemical properties and taste of meat, it is equally necessary to take into account the requirements of consumers, livestock breeders and the processing industry [7].

The aim of the research was to substantiate the influence of the breed on the productivity, quality and suitability of beef for baby food.

\section{Materials and methods}

Comparative studies of productivity, quality and safety of beef from black-andwhite dairy bulls and black-and-white crossbred bulls with Kalmyk beef breed have been carried out at the Bratkovsky Dairy Fattening Complex in the Korenovsky District of the Krasnodar Territory.

Calves were kept in individual huts for up to three months. The keeping of young stock for growing and fattening is loose in a sectional building with the same type of feeding in winter, and in a warm period - in feedlots.

Young animals in winter were kept in a room on slotted floors with an area of accommodation per head $-2.1 \mathrm{~m} 2$. In the period of 3-6 months, group cages of 15 heads were used.

Intensively fattening was from 6 months before slaughter at 18 months. The ration in the winter is silage-haylage-concentrate. The ration for one head contained according to the feeding periods, respectively, EFU - 7.4; 8.8; 9.7; dry matter - 7.5; 8.9; $9.5 \mathrm{~kg}$; crude protein $-1.1 ; 1.3 ; 1.4 \mathrm{~kg}$; digestible protein - $0.7 ; 0.8 ; 0.9 \mathrm{~kg}$; crude fiber - $1.4 ; 1.6 ; 1.7 \mathrm{~kg}$. Feeding diets are balanced for feeding periods with regard to nutritional value. The diet provided a live weight gain for the feeding period $900-1100 \mathrm{~g}$. The slaughter of bulls of two breeds, which reached slaughter conditions $(n=6)$, was carried out. Slaughter yield, mass fraction of meat, bones, fat, connective tissue were determined.

Research on beef bulls of the Charolais breed was carried out at the "Rubin" farm of the Goryacheklyuchevsky district of the Krasnodar Territory.

As of September 1, 2019, the Charolais breed of bulls in the beef cattle of the Goryacheklyuchevsky district amounted to $17 \%$. Agricultural lands of this region occupy more than 16 thousand hectares, including 15 hectares of hayfields, more than 13 thousand hectares of arable land and about 2 thousand hectares (12.5\%) of pastures, which are rich in herbs.

Bulls up to 8 months were raised according to the "cow-calf" technology. Fattening was carried out with year-round free grazing (up to 10 hours a day).

For feeding animals in winter, the farm uses its own concentrated, coarse and juicy feed.

In winter, the diet includes concentrates $(1.5-2.5 \mathrm{~kg})$, herb-legume hay, alfalfa haylage and corn silage and licks. In the final period of fattening, up to $4 \mathrm{~kg}$ of compound feed was introduced into the diet by reducing bulky feed.

The diet, conditions of feeding and keeping ensured the maximum manifestation of the genetic potential of the breed during the entire feeding period and ensured an increase in live weight of $1000-1200 \mathrm{~g}$. 
Control slaughter was carried out for 18 month old bulls $(n=6)$. The determination of the slaughter qualities of bulls was carried out in accordance with the methodological principles for assessing meat productivity and the quality of meat of cattle [8].

The morphological composition of carcasses, physical and chemical indicators of beef, safety in relation to residual amounts of toxic substances have been determined. The content of complete proteins was determined by the amount of an essential amino acid, tryptophan, and the content of incomplete proteins, by the amount of oxyproline. The protein quality index (PQI) is the ratio of tryptophan to hydroxyproline. Its value characterizes the complete properties of meat proteins.

\section{Results and discussion}

Morphological composition of carcasses 18 month old bulls of two breeds, meat yield and carcass composition are presented in Table 1.

Table 1. Quantitative indicators of meat productivity of non-castrated bulls of two breeds $(n=6)$

\begin{tabular}{|l|c|c|}
\hline \multirow{2}{*}{\multicolumn{1}{|c|}{ Items }} & \multicolumn{2}{|c|}{ Breed } \\
\cline { 2 - 3 } & Black-and-white & $\begin{array}{c}\text { Cross of black-and-white } \\
\text { with Kalmyk bulls }\end{array}$ \\
\hline Pre-slaughter live weight, $\mathrm{kg}$ & $480.0 \pm 21.0$ & $505.3 \pm 15.4$ \\
\hline Slaughter weight, kg & $274.1 \pm 3.2$ & $295.6 \pm 3.5$ \\
\hline Slaughter yield, \% & 57.1 & 58.5 \\
\hline Weight of fresh carcass, $\mathrm{kg}$ & $267.4 \pm 4.2$ & $283.0 \pm 3.4$ \\
\hline Carcass yield, \% & 54.7 & 56.0 \\
\hline Weight of chilled carcass, $\mathrm{kg}$ & $260.8 \pm 4.2$ & $280.2 \pm 2.9$ \\
\hline Beef yield, $\mathrm{kg}$ & $207.7 \pm 4.5$ & $231.7 \pm 3.0$ \\
\hline Beef yield, \% & 79.6 & 32.7 \\
\hline Bones and tendons, $\mathrm{kg}$ & 39.1 & 12.9 \\
\hline Bones and tendons, \% & 15.4 & 12.3 \\
\hline Visceral fat, $\mathrm{kg}$ & 14.0 & $4.4 \pm 1.2$ \\
\hline Visceral fat, \% & $5.0 \pm 1.3$ & \\
\hline
\end{tabular}

The Pre-slaughter live weight of 18-month-old bulls from crossing the black-and-white parent breed with Kalmyk beef bulls was significantly, by $5.3 \%$, higher than that of the black-and-white dairy-beef bulls.

The carcasses of crossbred bulls were superior to the carcasses of purebred bulls of the black-and-white breed in terms of the main slaughter indicators: the slaughter weight was $7.8 \%$; slaughter yield $-1.4 \%$; carcass yield $-1.3 \%$; the yield of boneless beef suitable for baby food $-3.1 \%$ higher.

The number of bones and tendons, as well as visceral fat in the carcasses of crossbred bulls was less, respectively, by 2.5 and $1.7 \%$.

These indicators confirm the influence of the genetic predisposition of the meat breed in the formation of meat productivity.

The qualitative characteristic of meat productivity is represented by the chemical composition of the longest muscle of bulls of two breeds at the age of 18 months. (Table 2).

Table 2. Physical and chemical composition of Longissimus dorsi, $\mathrm{n}=6$

\begin{tabular}{|c|c|c|}
\hline \multirow{2}{*}{ Item } & \multicolumn{2}{|c|}{ Breed } \\
\cline { 2 - 3 } & black-and-white & $\begin{array}{c}\text { cross of black-and-white } \\
\text { with Kalmyk bulls }\end{array}$ \\
\hline Color intensity, E x 1000 & 86.50 & 80.7 \\
\hline
\end{tabular}




\begin{tabular}{|l|c|c|}
\hline $\mathrm{pH}$ & 5.87 & 5.95 \\
\hline Mass fraction of moisture, \% & 68.60 & 68.10 \\
\hline Mass fraction of protein, \% & 19.80 & 20.30 \\
\hline Mass fraction of fat, \% & 10.75 & 10.70 \\
\hline including collagen + elastin & 1.90 & 0.90 \\
\hline Mass fraction of ash, \% & 0.85 & 244.00 \\
\hline Tryptophan, mg/100 g meat & 218.00 & 39.61 \\
\hline Hydroxyproline, mg/100 g meat & 37.59 & 6.16 \\
\hline PQI (protein quality index) & 5.80 & 8.57 \\
\hline Energy value of 1 kg of meat flesh, MJ & 8.49 & \\
\hline
\end{tabular}

The tryptophan to hydroxyproline ratio (PQI - protein quality index) of the longest muscle was 5.80 and 6.16, respectively, for beef from black-and-white bulls and its crosses with the Kalmyk breed. In the studies of some authors, the protein quality index of the longissimus dorsi muscle in black-and-white bulls and its crosses was also more than five, which indicates the high quality and biological value of beef [9].

The content of the amino acid lysine, which is limiting for the child's body, in the muscle tissue of the longest muscle of the back, respectively, of black-and-white and crossbreed bulls is 16.04 and $17.26 \mathrm{~g} / \mathrm{kg}$ (Table 3).

Table 3. Amino acid composition of Longissimus dorsi, in $\mathrm{g} / \mathrm{kg}$ of natural meat, $(\mathrm{n}=6)$

\begin{tabular}{|l|c|c|}
\hline \multirow{2}{*}{\multicolumn{1}{c|}{ Essential amino acid }} & \multicolumn{2}{c|}{ Breed } \\
\cline { 2 - 3 } & black-and-white & $\begin{array}{c}\text { cross of black-and-white } \\
\text { with Kalmyk bulls }\end{array}$ \\
\hline Mass fraction of protein & 198.00 & 203.00 \\
\hline Lysine & 16.04 & 17.26 \\
\hline Phenylalanine & 7.52 & 8.12 \\
\hline Leucine & 13.66 & 14.04 \\
\hline Isoleucine & 9.70 & 10.15 \\
\hline Methionine + cystine & 6.53 & 7.73 \\
\hline Valine & 11.88 & 11.77 \\
\hline Arginine & 11.48 & 11.99 \\
\hline Threonine & 8.32 & 8.73 \\
\hline Histidine & 6.53 & 6.51 \\
\hline Tryptophan & 2.18 & 2.44 \\
\hline Total essential amino acids, g/ kg & 93.84 & 98.74 \\
\hline Total essential amino acids, \% & 47.4 & 48.6 \\
\hline
\end{tabular}

The content of essential amino acids in $100 \mathrm{~g}$ of protein was from black-and-white bulls $47.4 \%$ and a cross between black-and-white and Kalmyk breeds $-48.6 \%$, which confirms the high nutritional value of beef.

The mineral composition of the longissimus dorsi muscle is shown in Table 4. 
Table 4. Essential macro- and microelements of Longissimus dorsi, $\mathrm{mg} / \mathrm{kg}(\mathrm{n}=6)$

\begin{tabular}{|l|c|c|}
\hline \multirow{2}{*}{ Element } & \multicolumn{2}{|c|}{ Breed } \\
\cline { 2 - 3 } & black-and-white & $\begin{array}{c}\text { cross of black-and-white with } \\
\text { Kalmyk bulls }\end{array}$ \\
\hline Potassium & 2400.000 & 2393.00 \\
\hline Phosphorus & 1100.000 & 1200.000 \\
\hline Sodium & 621.500 & 717.000 \\
\hline Magnesium & 149.000 & 151.000 \\
\hline Calcium & 102.120 & 103.500 \\
\hline Zinc & 36.130 & 34.540 \\
\hline Iron & 14.850 & 14.670 \\
\hline Copper & 7.880 & 7.380 \\
\hline Manganese & 0.102 & 0.108 \\
\hline Selenium & 0.023 & 0.030 \\
\hline Iodine & 0.023 & 0.026 \\
\hline Cobalt & 0.022 & 0.020 \\
\hline
\end{tabular}

The content of toxic substances in beef and by-products of the 1st category from bulls of two breeds was within the limits allowed by the requirements of the technical regulations of the customs union for baby food, table 5 .

Table 5. Safety of raw meat $(n=6)$

\begin{tabular}{|c|c|c|c|c|c|c|}
\hline \multirow[b]{2}{*}{ Safety indicator } & \multicolumn{6}{|c|}{ Meat raw material, $\mathrm{X} \pm \mathrm{m}$} \\
\hline & \multicolumn{2}{|c|}{ muscle tissue } & \multicolumn{2}{|c|}{ heart } & \multicolumn{2}{|c|}{ liver } \\
\hline Toxic elememnts: & $\begin{array}{l}\text { black-and- } \\
\text { white }\end{array}$ & cross & $\begin{array}{c}\text { black-and- } \\
\text { white }\end{array}$ & cross & $\begin{array}{l}\text { black-and- } \\
\text { white }\end{array}$ & cross \\
\hline Lead, $\mathrm{mg} / \mathrm{kg}$ & $0.042 \pm 0.03$ & $\begin{array}{c}30.030 \pm 0.0 \\
2\end{array}$ & $0.044 \pm 0.03$ & $0.035 \pm 0.03$ & $0.048 \pm 0.03$ & \begin{tabular}{|c|}
$0.042 \pm 0.0$ \\
3
\end{tabular} \\
\hline Cadmium, mg / kg & \multicolumn{2}{|c|}{$<0.01$} & \multicolumn{2}{|c|}{$0.01 \pm 0.01$} & \multicolumn{2}{|c|}{$0.01 \pm 0.01$} \\
\hline Mercury, mg / kg & \multicolumn{2}{|c|}{$<0.005$} & \multicolumn{2}{|c|}{$<0.005^{*}$} & \multicolumn{2}{|c|}{$<0.005^{*}$} \\
\hline Arsenic, mg / kg & \multicolumn{2}{|c|}{$<0.0025$} & \multicolumn{2}{|c|}{$<0.0025^{*}$} & \multicolumn{2}{|c|}{$<0.0025^{*}$} \\
\hline \multicolumn{7}{|l|}{ Antibiotics: } \\
\hline Tetracycline group, units / g & \multicolumn{2}{|c|}{$<0.01 *$} & \multicolumn{2}{|c|}{$<0.01 *$} & \multicolumn{2}{|c|}{$<0.01 *$} \\
\hline Bacitracin, units / g & \multicolumn{2}{|c|}{$<0.02 *$} & \multicolumn{2}{|c|}{$<0.02 *$} & \multicolumn{2}{|c|}{$<0.02 *$} \\
\hline $\begin{array}{l}\text { Levomycetin } \\
\text { (chloramphenicol), } \mathrm{mg} / \mathrm{kg}\end{array}$ & \multicolumn{2}{|c|}{$<0.0003 *$} & \multicolumn{2}{|c|}{$<0.0003 *$} & \multicolumn{2}{|c|}{$<0.0003 *$} \\
\hline Streptomycin, mg / kg & \multicolumn{2}{|c|}{$<0.2 *$} & \multicolumn{2}{|c|}{$<0.2^{*}$} & \multicolumn{2}{|c|}{$<0.2^{*}$} \\
\hline Penicillin, $\mathrm{mg} / \mathrm{kg}$ & \multicolumn{2}{|c|}{$<0.0025^{*}$} & \multicolumn{2}{|c|}{$<0.0025^{*}$} & \multicolumn{2}{|c|}{$<0.0025^{*}$} \\
\hline \multicolumn{7}{|l|}{ Pesticides: } \\
\hline $\begin{array}{l}\text { Hexachlorocyclohexane }(\alpha, \beta, \\
\gamma \text { - isomers), mg /кг }\end{array}$ & \multicolumn{2}{|c|}{$<0.004 *$} & \multicolumn{2}{|c|}{$<0.004 *$} & \multicolumn{2}{|c|}{$<0.004 *$} \\
\hline $\begin{array}{l}\text { DDT and its metabolites, } \mathrm{mg} / \\
\mathrm{kg}\end{array}$ & $<0.0$ & & $<0$. & $004 *$ & $<0.0$ & $04 *$ \\
\hline 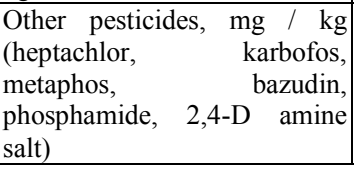 & & & not det & ected & & \\
\hline Mycotoxins: & & & & & & \\
\hline Aflatoxin $\mathrm{B}_{1}, \mathrm{mg} / \mathrm{kg}$ & $<0.00$ & $05^{*}$ & $<0.0$ & $005^{*}$ & $<0.00$ & $05^{*}$ \\
\hline Dioxins & & & not det & ected & & \\
\hline Hormonal preparations & & & not det & ected & & \\
\hline Radionuclides & & & & & & \\
\hline Cesium $137 \mathrm{~Bq} / \mathrm{kg}$ & 2. & & 2 & 4 & 2.5 & \\
\hline Strontium $90 \mathrm{~Bq} / \mathrm{kg}$ & - & & 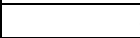 & - & - & \\
\hline
\end{tabular}


Note: * "not detected" - below the detection limit of the method; ** - control over the content of dioxins is carried out in cases of deterioration of the ecological situation associated with accidents, man-made and natural disasters leading to the formation of dioxins. Determination of hormonal preparations is carried out on demand based on the information received on their use provided by the manufacturer (supplier) of raw materials when supplied for processing.

In terms of safety indicators, taking into account the maximum permissible levels of residual amounts of pesticides, toxic elements, antibiotics, meat raw materials from beef and dairy black-and-white bulls and a cross with a Kalmyk breed met the requirements of the standard for raw materials for baby food.

The morphological composition of carcasses, meat yield and its chemical composition were studied at 18 month old Charolais bulls (Table 6).

Table 6. Results of slaughter of Charolais bulls, 18 months old $(n=6)$.

\begin{tabular}{|l|c|}
\hline \multicolumn{1}{|c|}{ Item } & Result, $\mathbf{X} \pm \mathbf{m}$ \\
\hline & \\
Pre-slaughter weight, $\mathrm{kg}$ & $580.0 \pm 5.1$ \\
\hline Weight of fresh carcass, $\mathrm{kg}$ & $377.0 \pm 3.3$ \\
\hline Carcass slaughter yield, \% & 65.0 \\
\hline Weight of chilled carcass, kg & $372.7 \pm 3.1$ \\
\hline $\begin{array}{l}\text { Beef yield, } \mathrm{kg} \\
\%\end{array}$ & $298.2 \pm 3.0$ \\
\hline $\begin{array}{l}\text { Bones and tendons, } \mathrm{kg} \\
\%\end{array}$ & 80.0 \\
\hline $\begin{array}{l}\text { Visceral fat, } \mathrm{kg} \\
\%\end{array}$ & $64.10 \pm 1.0$ \\
\cline { 2 - 2 } & 17.2 \\
\hline
\end{tabular}

Physicochemical composition of the longest muscle of Charolais bulls at the age of 18 months is presented in tables 7 and 8.

Table 7. Physical and chemical composition of Longissimus dorsi, $\mathrm{n}=6$.

\begin{tabular}{|l|c|}
\hline \multicolumn{1}{|c|}{ Item } & Result, $\mathrm{X} \pm \mathrm{m}$ \\
\hline Mass fraction of moisture, \% & 69.8 \\
\hline Mass fraction of protein, \% & 19.8 \\
\hline Mass fraction of fat, \% & 9.20 \\
\hline Mass fraction of ash, \% & 1.0 \\
\hline Color intensity, E x1000 & 81.8 \\
\hline pH & 5.92 \\
\hline incl. collagen + elastin & 1.92 \\
\hline Tryptophan, mg / 100 g meat & 317.00 \\
\hline Oxyproline, mg / 100 g of meat & 48.77 \\
\hline PQI & 6.5 \\
\hline
\end{tabular}

The PQI of the longest muscle (longissimus dorsi) was 6.5.

Table 8. Essential macro- and microelements of Longissimus dorsi, $\mathrm{mg} / \mathrm{kg}(\mathrm{n}=6)$

\begin{tabular}{|l|c|c|}
\hline Element & \multicolumn{2}{|c|}{$\mathbf{X} \pm \mathbf{m}$} \\
\hline Potassium & 2130.50 & 2115.70 \\
\hline Phosphorus & 1260.00 & 1285.00 \\
\hline Sodium & 530.50 & 580.00 \\
\hline Magnesium & 224.00 & 245.00 \\
\hline Calcium & 100.10 & 98.00 \\
\hline
\end{tabular}




\begin{tabular}{|l|c|c|}
\hline Zinc & 19.80 & 14.83 \\
\hline Iron & 18.79 & 21.15 \\
\hline Copper & 10.70 & 12.00 \\
\hline Manganese & 0.16 & 0.18 \\
\hline Selenium & 0.055 & 0.069 \\
\hline Iodine & 0.047 & 0.058 \\
\hline Cobalt & 0.020 & 0.022 \\
\hline
\end{tabular}

The content of lysine, a limiting amino acid for a child's body, in the longissimus dorsi muscle was $19.76 \mathrm{~g} / \mathrm{kg}$ (Table 9).

Table 9. Amino acid composition of Longissimus dorsi, $\mathrm{n}=6$

\begin{tabular}{|l|c|}
\hline \multicolumn{1}{|c|}{ Essential amino acid } & $\mathrm{g} / \mathrm{kg}$ natural meat \\
\hline Mass fraction of protein, \% & 198.00 \\
\hline Lysine & 19.76 \\
\hline Phenylalanine & 7.09 \\
\hline Leucine & 11.43 \\
\hline Isoleucine & 8.46 \\
\hline Methionine + cystine & 7.05 \\
\hline Valine & 8.34 \\
\hline Arginine & 12.35 \\
\hline Threonine & 9.69 \\
\hline Histidine & 9.11 \\
\hline Tryptophan & 2.94 \\
\hline Total essential amino acids, $\mathrm{g} / \mathrm{kg}$ & 98.22 \\
\hline$\%$ & 49.61 \\
\hline
\end{tabular}

The content of essential amino acids in $100 \mathrm{~g}$ of protein was $49.61 \%$. In terms of safety indicators (maximum permissible levels of residual amounts of toxic substances), meat raw materials from bull calves of both farms met the requirements of the interstate standard for baby food.

\section{Conclusion}

The requirements for the quality of meat for baby food and its safety have significantly expanded. The principles of HACCP (Hazard Analysis and Critical Control Points) are applied in the development of the production technology and quality management [10]. The breed and type of fattening of young cattle affect the productivity, quality and suitability of beef for baby food products (Table 10).

Table 10. Comparative indicators of productivity, chemical

And biological value of raw meat of 18 month old bulls of different breeds, $\mathrm{n}=6$.

\begin{tabular}{|l|c|c|c|}
\hline \multirow{2}{*}{\multicolumn{1}{|c|}{ Item }} & \multicolumn{2}{c|}{ Breed } & Charolais \\
\cline { 2 - 4 } & Black-and-white & black-and-white * Kalmyk & $580.0 \pm 5.1$ \\
\hline Live weight, kg & $480.0 \pm 21.0$ & $505.3 \pm 15.4$ & 65.0 \\
\hline Slaughter yield, \% & 57.1 & 58.5 & 80.0 \\
\hline Meat yield, \% & 75.0 & 77.5 & 69.8 \\
\hline Mass fraction of moisture, \% & 65.6 & 66.1 & 9.2 \\
\hline $\begin{array}{l}\text { Mass fraction of fat in muscle } \\
\text { tissue of Longissimus dorsi, \% }\end{array}$ & 10.8 & 10.7 & 19.8 \\
\hline Mass fraction of protein, \% & 19.8 & 20.3 & 19.8 \\
\hline Lysine, g/kg & 16.0 & 17.3 & 6.50 \\
\hline PQI (protein quality index) & 5.80 & 6.16 & 49.61 \\
\hline $\begin{array}{l}\text { Essential amino acids in 100 g of } \\
\text { protein, \% }\end{array}$ & 47.4 & 48.6 & \\
\hline
\end{tabular}


Charolais bulls, zoned in the period 2012-2019, were optimally acclimatized in the foothill raw material zone, which was facilitated by the effective use of natural rangelands. Based on the studies carried out and the generalization of the data obtained, the following conclusions can be drawn:

1. We found that the physical and chemical characteristics of meat depend on the breed. These results are confirmed by foreign studies that have proven that the quality characteristics of meat depend on the breed and are inherited and can be regulated by selection [11 - 15].

2. By the age of 18 months, Charolais bulls reached a live weight of $580.0 \pm 5.1 \mathrm{~kg}$, which, respectively, is 74.7 and $100 \mathrm{~kg}$ more than that of black-and-white and black-and-white crossbred bulls from the Kalmyk breed $(\mathrm{p} \leq 0.001)$. In terms of protein quality indicator (6.5), beef from Charolais bulls exceeded the rest (6.16 and 5.8).

3. The Charolais breed has the best protein composition $(19.8 \mathrm{~g} / \mathrm{kg}$ of lysine, the limiting amino acid for the child's body). This allows us to consider the Charolais breed more promising for pasture feeding technology.

4. In terms of safety indicators, taking into account the maximum permissible levels of residual amounts of pesticides, toxic elements, antibiotics, meat raw materials from Charolais bulls, beef and dairy black-and-white and a cross with a Kalmyk breed met the requirements of the interstate standard of Russia for raw materials for baby food and approached GFSI (Global Food Safety Initiative).

The research results will be used by the suppliers of beef of the Tikhoretsky Children's Meat Factory Branch of DANON RUSSIA JSC for the production of meat-based baby food.

\section{References}

1. D. Bureš, L. Bartoň, Czech J. Anim. Sci., 57(1), 34-43 (2012)

2. M. Christensen, P. Ertbjerg, S. Failla, C. Sañudo, R. I. Richardson, G.R. Nute, J. L. Olleta, B. Panea, P. Albertí, M. Juárez, J. F. Hocquette, J. L. Williams, Meat Science, 87(1), 61-65 (2011) Doi: 10.1016/j.meatsci.2010.09.003

3. L. Bartoň, D. Bureš, V. Kudrna, American Journal of Food Science and Technology, 2(6), 192-195 (2014) Doi: 10.12691/ajfst-2-6-4

4. A. Waritthitham, C. Lambertz, H. J. Langholz, M. Wicke, C. Lambertz, Meat quality. Meat Science, 85(1), 196-200 (2010) https://Doi.org/10.1016/j.meatsci.2009.12.025

5. C. A. Ramírez-Restrepo, D. V. Tien, N. Le Duc, M. Herrero, P. Le Dinh, D. Dinh Van, Sen Le Thi Hoa, C. Vu Chi, C. Solano-Patiño, A. M. Lerner, T. D. Searchinger, Asian-Australasian Journal of Animal Sciences (AJAS); 30(7), 1054-1060 (2017)

6. N. V. Konik, L. N. Skorykh, O. A. Shutova et al., Research journal of pharmaceutical, biological and chemical sciences, 9(4), 607-612 (2018)

7. D. Parsons, N. H. Van, A. E. O. Malau-Aduli, N. Xuan Ba, Le Dinh Phung, P. A. Lane, Le Duc Ngoan, L. O. Tedeschi, Asian-Australas J Anim Sci. Sep., 25(9), 1237-1247 (2012) DOI: 10.5713 / ajas.2012.12036

8. F. W. Mwangi, E. Charmley, C.P. Gardiner, B. S. Malau-Aduli, R.T. Kinobe, and A. E. O. Malau-Aduli, Foods, 8(12), 648 (2019) https://doi.org/10.3390/foods8120648

9. J. Rodriguez, J. Unruh, M. Villarreal-Castro, O. Murillo, Meat Science, 96(3), 13401344 (2013) DOI: 10.1016/j.meatsci.2013.10.024S

10. M. D. Erdin, International Journal of Quality \& Reliability Management, 33(9), 14061412 (2016) Doi: 10.1108/IJQRM-03-2015-0042 
11. H. Gebrehiwot, E. Balcha, Y.s Hagos and K. W/rkelul, Journal of Veterinary Medicine and Animal Health, 10(6), 159-164 (2018) DOI: 10.5897/JVMAH2018.0680.

12. J. K. Cheong, Y. T. Oh, H. N. Choi, C. H. Lee, et al., J Anim. Sci. Technology, 54(2), 47-52 (2012)

13. S. Tóth, M. Kovács, B. Bóta, J. Szabó-Fodor, G. Bakos, H. Fébel, Czech Journal of Animal Science, 64(9), 367-376 (2019) https://Doi.org/10.17221/34/2019-CJAS.

14. A. N. Postolache, Ş. Creangă, E. Ruginosu, D. L. Dascălu, S. I. Borş., Animal Science and Biotechnologies, 47(2) (2014)

15. J. Rodriguez, J. Unruh, M. Villarreal-Castro, O. Murillo, Meat Science, 96(3), 13401344 (2013) DOI: 10.1016/j.meatsci.2013.10.024 